\title{
Inbalt des XVII. Bandes (2. Teil)
}

Blatweiser . . . . . . . . . . . . . . . 1

Varianten . . . . . . . . . . . . . . . . . 207

Nacbwort des Herausgebers . . . . . . . . . . . . . 209

Anbang zu "Heidnische Gottheiten" . . . . . . . . . 225 
